\title{
Environmental Education to Education for Sustainable Development: Challenges and Issues
}

\author{
Abdourakhmane NDIAYE \\ Faheem KHUSHIK \\ Arnaud DIEMER \\ Francine PELLAUD \\ University of Clermont-Ferrand, CERDI, France \\ HEP Fribourg \\ Switzerland
}

\begin{abstract}
If the implementation of Education for Sustainable Development national educational policies and strategies has taken place in a context in whichEnvironmental Education was already well established, it has been widely institutionalized by the United Nations Decade of Education for Sustainable Development. a UNESCO programme. The aim of ESD is to encourage changes in education so that it can effectively contribute to the reorientation of societies towards sustainable development. It proposes participatory methods of teaching and learning such as critical thinking, the imagination of future scenarios, and collaborative decision-making to enable learners to take the actions necessary for sustainable development.
\end{abstract}

Keywords: Environmental Education, ESD, UNESCO, Sustainability, Values

If Education for Sustainable Development (ESD) has been implemented in most countries (UNESCO, 2018), we must not forget that Western and Southern countries had gone through the "environmental education" phase before applying the international framework for "education for sustainable development" agreed by UNESCO. This historical trajectory explains in large part why sustainable development is very often associated with the emergence of the concept of the environment. It also makes it possible to identify two educational projects with different outlines.

Environmental Education (EE) emerged in 1977 at the Stockholm UNCSD. It was conceived as a process in which individuals and the community become aware of their environment and acquire the knowledge, values, skills, experience, and the willingness to act individually and collectively, to solve current and future environmental problems. Lucie Sauvé (1998, p. 15) points out that "EE is considered as this dimension of contemporary education that is concerned with rebuilding the network of relationships between people - social group - environment". The environment istaken to be an eco-socio-system, characterized by the interaction of its biophysical and social components. Environmental education is first and foremost a project concerned with "society".

Education for Sustainable Development has taken a different path. In December 2002, the United Nations General Assembly adopted resolution 57/254 proclaiming the United Nations Decade of Education for Sustainable Development. This initiative completed a series of texts (Chapter 36 of Agenda 21, provision 124) adopted at the United Nations Conference on Environment and Development (Rio de Janeiro, June 1992) and the World Summit on Sustainable Development (Johannesburg, September, 2002). UNESCO was entrusted with the responsibility of leading this Decade and developing a draft international implementation programme. Education for Sustainable Development thus became a political project, which was formalized by the major international and national institutions. As such, the International Implementation Scheme for the United Nations Decade of Education for Sustainable Development considers that ESD

"is based on the principles and values that underpin sustainable development; concerns the good health of the three spheres of sustainability (environment, society and economy); promotes lifelong learning; is locally relevant and culturally appropriate; is based on local needs, attitudes and conditions, 
But recognizes that meeting local needs often has international implications; mobilizes formal, non-formal and informal education; adapts to the evolving concept of sustainability; addresses content taking into account context, international issues and local priorities; builds citizens' capacities in the areas of community decisionmaking processes, social tolerance, environmental management, labour flexibility and quality of life; and is interdisciplinary. ESD is not the exclusive domain of any discipline, but all disciplines can contribute to ESD; it uses a variety of pedagogical techniques that promote participatory learning and the acquisition of high intellectual skills" (UNESCO, 2005, p. 35-36).

In what follows, we will look at the history and epistemology of Environmental Education and Education for Sustainable Development to identify the major trends facing our education systems up to 2030. The SDGs initiated by the United Nations give ESD a key role in the Quality Education Goal (SGD 4). The good practice promoted by UNESCO should not let us forget that ESD can only truly change education systems if it offers a real methodological approach to learners. First of all, it is difficult to educate people about the environment (purists talk mainly about environmental education) without going back to the notion of the environment. From a historical point of view, this concept refers mainly to the debates about the conservation and preservation of biodiversity (Muir/Pinchot) in the 19th and 20th centuries. In the 1960s, the concept gained new momentum with the work of Carson and Commoner. It was only in the 1970s that environmental education gained its present status.

\section{The Environmental Issue}

Initially introduced as part of the study of Geography, the concept of environment has gradually become nomadic and polysemic (Matagne, 2003). Both complex and incorporating different fields of knowledge (architecture, ecology, etc), it currently refers to very diverse practices, values and representations. According to Theys (1993), the environment is the subject of permanent social negotiation about the boundaries of private/public, culture/nature, technical/logic ideas of life, and its reality is contextualised. These multiple dimensions associated with the environment emanate from different schools of thought based on different visions because they are based on very different representations of our perception of the environment. They question how we, as human beings, view ourselves within nature. Are we living beings who have a vocation to dominate nature? Or are we living beings among others, integrated into the laws of nature and dependent on our natural environment? These representations are strongly linked to the history of peoples, religions, and science.

From its beginning, Christianity has endeavoured to propose a vision of Man as master of nature, and therefore of divine creation. Nature is at the service of man, but man is at the same time responsible for it: Genesis 1:26: "Then God said, "Let us make man in our image, according to our likeness, and let him rule over the fish of the sea, over the birds of the air, over the cattle, over all the earth, and over every creeping thing that creeps on the earth. God created man and woman. And said to them, be fruitful, multiply, fill the earth, and subdue it; and rule over the fish of the sea, over the birds of the air, and over every beast that moves on the earth."

In recent centuries Science has dethroned religious power while continuing to convey a degraded image of nature. Nature is reduced to a stock of resources from which we happily draw by developing increasingly sophisticated techniques. The scientific progress of the industrialized countries has led to the imposition of its vision of world development. This purely instrumentalized representation of nature, radically anthropocentric, has been challenged in recent years by the recognition of the environmental disaster that progress generates. This recognition makes usmore humble because our control of anthropogenic impacts on ecosystems is very limited. The anthropocentric concepts are nuanced. According to B. Kalaora (1992), "man's struggle is no longer between himself and nature, but with himself, with the ultimate goal of survival for both". The representation of double decentralization (J. Davallon, G. Grandmont, B, Schiele, 1992) illustrates this vision. Man no longer appears at the centre of nature or even in front of it; but both inside and outside it (Boissot). This decentralization resituates Man in time, and makes it possible to revisit his biological origins, his kinship with the living, his animal dimension; and to put Man in perspective with his human, cultural and scientific history, thus revealing his double belonging: natural as a biological animal, cultural as a human capable of knowing and controlling (J. Davallon, G. Grandmont, B. Schiele, 1992). It challenges entrenched identity reflexes to propose a composite identity. Lucie Sauvé (1991) proposed a typology of representations of the human/environment relationship (cognitive approach, sensory approach, emotional approach, pragmatic approach, moral or ethical approach, spiritualist approach, experiential approach, cooperative approach, interdisciplinary approach, critical approach, reflective approach). 
Using the Boillot test (followingChapuy), she said that it was possible to distinguish, among other things, environment/nature or environment/biosphere representations (biocentric vision), environment/problem and environment/resource (eco-sociocentric vision), environment/living environment and environment/community (sociocentric vision).

These typologies are not designed to lead to reductive thinking about representations because the representations are multiple and nuanced. The typologies make it possible to decode some of our human behaviour in terms of the environment, and to move towards a more precise understanding of the ambiguous and complex relationship we have with nature. These typical representations are part of fundamentally different world views, inform our decision-making, guide our future directions, and ultimately question our dominant place as a species in the biosphere. The visions outlined in the table, which are widely developed in the literature, coexist in each of us. They guide our choices and actions at the individual and collective level. They are part of our system of representation of the world, a model which is derived from our social and cultural experience.

Table 1: Typology of representations Human/ Nature

\begin{tabular}{|c|c|c|c|}
\hline Visions & $\begin{array}{l}\text { Dominance } \\
\text { Relationships }\end{array}$ & Conceptual Map & Practices of ERE \\
\hline $\begin{array}{c}\text { Objective } \\
\text { object relationships } \\
\text { BIOCENTRIC } \\
\text { qualitative approach to nature } \\
\text { Purpose: conservation and } \\
\text { knowledge, belonging to nature }\end{array}$ & $\mathrm{N}$ & ECOSYSTEM & $\begin{array}{l}\text { ENVIRONMENT } \\
\text { NATURE } \\
\text { Study of the } \\
\text { environment, sensory } \\
\text { approach } \\
\text { ENVIRONMENT } \\
\text { BIOPSHERE } \\
\text { living together, } \\
\text { planetary } \\
\text { consciousness }\end{array}$ \\
\hline $\begin{array}{c}\text { Recursive } \\
\text { object - subject relations } \\
\text { TECHNOCENTRIC } \\
\text { Purpose: sustainable } \\
\text { development, management, } \\
\text { expertise }\end{array}$ & $\mathrm{N}$ & $\begin{array}{l}\text { ECOSOCIO } \\
\text { SYSTEM }\end{array}$ & $\begin{array}{c}\text { RESOURCE } \\
\text { ENVIRONMENT } \\
\text { resource management } \\
\text { SYSTEM } \\
\text { ENVIRONMENT } \\
\text { Industrial ecology }\end{array}$ \\
\hline $\begin{array}{l}\text { Subjective } \\
\text { subject's relationship to the } \\
\text { object } \\
\text { ANTHROPOCENTRIC } \\
\text { Purpose: quality of life, cultural } \\
\text { heritage, social utility }\end{array}$ & $\mathrm{N}$ & SOCIO SYSTEM & $\begin{array}{l}\text { ENVIRONMENT } \\
\text { CULTURE } \\
\text { creative individual } \\
\text { culturally rooted } \\
\text { ENVIRONMENT } \\
\text { POLITICS } \\
\text { politically anchored } \\
\text { creative individual } \\
\text { ENVIRONMENT } \\
\text { COMMUNITY }\end{array}$ \\
\hline
\end{tabular}

Source: Theys (1993), Sauvé (1991), Diemer, Marquat (2014, 2015)

\section{When the environment goes hand in hand with Nature protection}

The emergence of the concept of the environment historically is rooted in two types of debates. The first debate is the division of views that has animated the American ecological movement since the end of the 19th century (Boidin, Diemer, Figuière, 2014). This debateis about two different visions of nature protection: that of preservationassociated with John Muir (1838 - 1914) and that of conservation associated with Gifford Pinchot (1865 - 1946). This schism between preservation and conservation still appears today as the backdrop to all major biodiversity debates. The various conferences and reports of international organizations oscillate between these two visions. The second debate has been inspired by the positions taken by the Nature Writers in the 1960s and 1970s. Rachel Carson (Silent Spring, 1962) and Barry Commoner (Closing Circle, 1971) embody this scientific approach to inform and educate the general public about the damage caused to the environment by human activities. 


\subsection{Origin of the schism in nature protection movements}

At the end of the 19th century, the American ecological movement was the scene of a split between supporters of nature preservation (John Muir) and those of nature conservation (Gifford Pinchot). The relationship between the two men had started well. They met for the first time in New York in 1893, and they participated three years later in a Forestry Commission. The members of this commission travelled throughout the American West and observed the damage inflicted by humans on nature. It was this love of nature that led Pinchot and Muir to take long walks together in forests (Larrère, 2007). Their friendship ended in the summer of 1897 when Pinchot published a statement in the Seattle Journal encouraging domestic sheep grazing in forest reserves. Muir strongly opposed this position, stating that "hoofed locusts" should not be allowed to trample the forest. The opposition between the two men fuelled the columns of many popular magazines (Outlook, Harper's Weekly, Atlantic Monthly, World's Work, and Century), and even took on a national character when the American government decided to build a dam on the Tuolumne River to supply water to the city of San Francisco. John Muir opposed the flooding of the HetchHetchy Valley (he wrote an open letter to Theodore Roosevelt imploring him to cancel the project),but Gifford Pinchot supported the construction of the dam. After several years of debates that divided the country, Roosevelt's successor, Woodrow Wilson signed the decree authorizing the construction of the dam on December 19, 1913.

The Pinchot/Muir schism symbolizes the history of nature protection movements (the exploitation of natural resources and more specifically of forests - Smith, 1998). On the one hand, John Muir, is one of the first modern naturalists. His essays and travel diaries are both novels of adventures in hostile regions (Alaska, Great Sierra, Cuba, etc) and true hymns to nature (sketches of forest trees, meadows, lakes, glaciers, moraines, mountain passes, etc). Reproaching men for their utilitarian approach, Muir intended to preserve nature and its resources for their intrinsic and spiritual value: "None of the dogmas professed by contemporary civilization seems to form a more insurmountable obstacle to a healthy understanding of the relationship that culture has with the wild state than one who considers that the world has been made especially for human use. Any animal, plant or crystal contradicts it in the most formal way. Now it is taught from century to century as something precious and always new, and in the darkness that results from it this monstrous claim can go freely its way" (Muir, 2011, p. 23). The notion of preservation means protection from destruction or degradation (Larrère, Larrère, (??) 1997). Nature must be preserved in its original purity. The term "wilderness", which has no equivalent in French, refers to pristine natural environments which cover vast areas (which is the case in North America and Canada). Largely uninhabited, these environments sometimes harbour scattered, non-sedentary groups of humans with so-called primitive cultures. According to the Wilderness Act (1964), man is "at most a visitor who does not stay". Paul Arnoult and Eric Glon(2006, p. 228) point out that it was "the Anglo-Saxon settlers and their descendants who founded this idea of wilderness according to their own beliefs and cultural references". Wilderness is outside the social sphere because this nature is not part of the civilization and mental universe of its inhabitants. Deeply influenced by the work of Henri David Thoreau and his book Walden ou la vie dans les bois, Muir challenged the predatory exploitation of natural resources and defended the idea of an ethics of nature. His efforts to improve the protection of natural areas led him to create the Sierra Club (1892), one of the most important environmental associations in the United States (the first non-governmental organization concerned with environmental protection, which today has over 700,000 members), and to initiate a vast movement to recognize national parks in the United States (e.g. Yellowstone). His writings and philosophy have influenced the modern environmental movement.

On the other hand, Gifford Pinchot, was an American forester with a background in European forest management methods. Pinchot was influenced by Carl Shurz, American Secretary of State for the Interior from 1871 to 1881, who was very fond of forest management, and Bernhard Fernow, who was appointed Head of the Forest Division at the Department of Agriculture in 1886. Both were trained in scientific forestry developed in Germany, their country of origin. It is under this influence, as well as that of the French school, that Pinchot "draws the ferments of his conservationism" (Glon, 2006, p. 251). Pinchot saw conservation as an intelligent way to manage the country's resources. Conservation is the desire to defend, keep resources in good condition, and prevent their destruction. In his book The Fight forConservation (1910), Pinchot promotes scientific forestry and promotes the profitable (but controlled) use of forests and other natural resources. Its approach is based on three fundamental concepts: economic development, utilitarian reasoning, and nature protection. First, the forest is considered as a vast reservoir at the disposal of the American nation's economic development, and not of a minority of forestry companies: "The first great fact about conservation is that it stands for development" $(1919$, p. 27$)$. 
Pinchot advocates a wise use of forest resources and condemns the short-term selfishness of those who make the forest disappear for their personal interest. Catherine Larrère (2007, p. 4) notes that his utilitarian reasoning can be summed up as "the greatest good of the greatest number for the longest time". An expression that is reminiscent of Bentham's formula: "the greatest happiness of the greatest number". While Pinchot prefers the rhetoric of the market economy to the expansion of the government's role in protecting nature, he advocates setting aside forests for future needs. By laying the foundations for conservationism in the United States and Canada (first conference in 1906), Pinchot's ideas found a favourable echo within the American Forestry Association which was created in 1875. The creation of forest reserves for future exploitation and to protect agricultural areas, the creation of forest fire-fighting services, and reforestation after logging are some of the many illustrations of forest management from a conservationist perspective. In addition, Pinchot founded the Yale University School of Forestry in 1900 and became the first head of the American Forest Service (part of the Department of Agriculture) in 1905. As an advisor, Pinchot inspired Theodore Roosevelt's environmental and natural resources policy from 1901 to 1909.

In the second half of the 20th century, these two currents took contrasting directions. On the one hand, John Muir inspired the environmental ethics movement (Larrère, 2007) which developed around two questions: that of the intrinsic value of nature (as opposed to the instrumental value), and that of wilderness as a model of nature to be protected. A moral philosophy has been built around the concepts of anthropocentrism (man is considered as the central entity, reality is apprehended through the sole human perspective), biocentrism (all living beings have an intrinsic value, which gives them the right to respect), ecocentrism (the emphasis here is on the interconnection of life forms within a complex and harmonious whole, all living beings are part of a biotic community), sociocentrism (seeing in the environment only one way of problematizing society and in nature only one place to walk), or pathocentrism (taking into account a centrality of suffering or suffering common to all living beings). The preservation current saw its hours of glory with the creation of the IUPN (International Union For the Preservation on Nature) in 1948 (Bordeaux International Conference), and the proclamation of the US Wilderness Act in 1964. Thisfederal law on the protection of nature, drafted by Howard Zahniser of the Wilderness Society, defines wilderness as "a space where the earth and the community of life are not hindered by man, where man himself is only a passing visitor". On the other hand, Pinchot's ideas and the conservationist vision of nature are still very much alive in the debates about sustainable development and biodiversity protection: this is the case of the IUPN renamed in 1956 the International Union for the Conservation of Nature (IUCN) and the findings of the Brundtland report, in which the banking of forests for future needs is considered to be for future generations.

\subsection{Environmental degradation: the Nature Writers' warning message}

The contributions of the Nature Writers seem play a key role in the perception and representation of damage to the environment. With an international scientific reputation, they took up writing in the 1960s and 1970s to alert public opinion to environmental degradation. Rachel Carson and Barry Commoner are the emblematic figures. Their struggle is now part of the history and epistemology of the environmental movement.

\section{Figure 1: The Nature Writers, alarming the world}

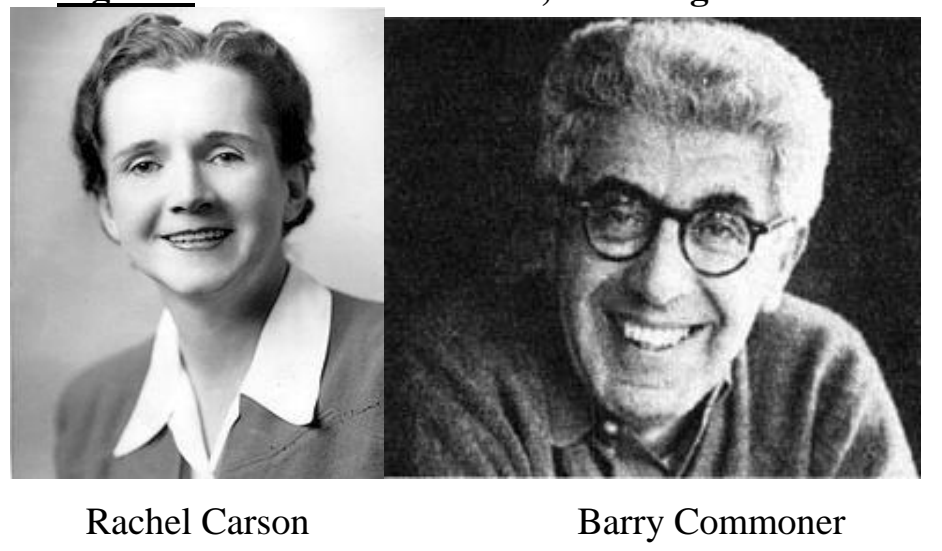

Rachel Carson (1907-1964), an internationally renowned marine biologist, referred in her book Silent Spring to the environmental problems caused by DDT. The introduction of the book entitled "A fable for tomorrow" imagines a town in the heart of America where all life seemed to live in harmony with its surroundings: "The town lay in the midst of a checkerboard of prosperous farms, with fields of grain and hillsides of orchards where, in spring, white clouds of bloom drifted above the green fields" (1962, p. 1). 
Then, a strange blight crept over the area and everything began to change. Some evil spirit had settled on the community: mysterious maladies swept the flocks of chickens; the cattle and sheep became sick and died. There were several sudden and unexplained deaths, not only among adults but even among children, who would be stricken suddenly while at play and die within in few hours. After a long description of the scene, Rachel Carson admitted that this town does not actually exist, but it might easily have a thousand counterparts in America or elsewhere in the world. The book is an attempt to explain how we have arrived here. One species, man,has acquired enough power to alter the nature of the world. Man's power has not only increased to a disturbing magnitude, but also it has changed in character. The most alarming of all man's assaults upon the environment is the contamination of air, earth, rivers, and seas with dangerous and even lethal materials: "In this now universal contamination of the environment, chemicals are the sinister and little recognized partners of radiation in changing the very nature of the world - the very nature of its life" $(1962, \mathrm{p} .6)$.

Rachel Carson tells us that since the mid-1940's over 200 basic chemicals have been created for use in killing insects, weeds, rodents, and other organisms described as "pests". These sprays and powders are now applied almost universally to farms, gardens, forests, and homes. The whole process of spraying seems caught up in an endless spiral. Since Dichloro-Diphenyl-Trichloro-ethane (DDT)was released for civilian use, a process of escalation has been going on in which ever more toxic materials must be found. For Carson, the central problem has therefore become the contamination of man's total environment with such substances which have an incredible potential for harm - substances that accumulate in the tissues of plants and animals, and even penetrate germ cells to alter the material of heredity upon which the shape of the future depends. In the USA the production of synthetic pesticides increased from 124,259,000 lbs in 1947 to 637,666, $000 \mathrm{lbs}$ in 1960 (more than a fivefold increase). So, if pesticides are part of our life, if we are going to eat and drink them, allowing them into the marrow of our bones, we have to know something about their nature and their power. Silent Springis both a wakeup call and an investigation of the workings of the chemical industry. The book points out how DDT and related chemicals are passed on from one organism to another through all the links of the food chains. It also accuses the chemical industry of intentional misinformation, and public authorities of accepting the industry's claims without question. Rachel Carson's battle against the chemical lobby, and the scientific arguments she used to describe the situation, inspired the creation of the US Environmental Protection Agency, and she was posthumously awarded the Presidential Medal of Freedom.

Barry Commoner (1917-2012) was a committed opponent of nuclear tests by showing the presence of strontium 90 in children's teeth. Director of the Centre for Biology and Natural Systems Studies at Queens College (New York), he received the International Humanist Award in 1970. Barry Commoner is the author of two best-selling books: Science and Survival (1966) and Closing Circle: Nature, Man and Technology (1971). In Closing Circle, Commoner presents what he calls the environment crisis and the purpose of his writings: "Earth Week convinced me of the urgency of a deeper public understanding of the origins of the environmental crisis and its possible cures. That is what this book is about. It is an effort to find out what the environmental crisis means" (1971, p. 11). Commoner traced the environmental crisis back from its overt manifestations in the ecosphere to the ecological stresses which they reflect, to the faults in productive technology (and its scientific basis) that generate these stresses, and finally to the economic, social, and political forces which have driven humankind down this self-destructive path. Closing Circlediscusses the rapid growth of industry and technology and their persistent effect on all forms of life. It suggests that we can reduce the negative effects by sensitizing, informing, and educating ourselves about our connection to the natural world. It also presents the basics of ecology in what Commoner termed "Laws of Ecology". A way to propose simple statements that help us understand and remember our connections to nature.

The first law of ecology- Everything is connected to everything else - toremind us of the existence of an elaborate network of interconnections in the ecosphere, between different living organisms. An ecosystem consists of multiple interconnected parts. Our ability to understand the behaviour of such a system has been improved by the development of ecology and cybernetics. The second law of ecology - Everything must go somewhere - means that in every natural system, what is excreted by one organism as waste is taken up by another one as food. This is the trophic chain - carbon dioxide captured by plants which excrete oxygen, which is used by animals, and so on.The third law of ecology - Nature knows best -holds that any major man-made change in natural system is likely to be detrimental to that system. The example of DDT can be used here: the fact that the DDT is not found in nature, that somewhere, at some time in the past, some unfortunate cell synthesized this molecule - and died. 
Given these ideas, Commoner proposes to treat man-made changes, especially chemical ones, prudently and cautiously. The fourth law ofecology - There is no such thing as a free lunch -warns that nothing can be gained without cost. Any exploitation of nature involves an ecological cost "Because the global system ecosystem is connected whole, in which nothing can be gained or lost and which is not subject to over-all improvement, anything extracted from it by human effort must be replaced" (1971, p. 46). These four laws form the basis for studying and understanding the relationships and interdependencies found in communities and ecosystems. They also indicate that humankind is only one part of the biotic community and that people are shaped and nurtured by the characteristics of the land. These laws do not explain everything, mysteries will remain, but the laws give a clearer understanding and appreciation of ecology.

While Barry Commoner and Rachel Carson's books demonstrate a certain scientific rigour (collection and processing of information), they also highlight the commitment of scientists to the environmental cause. They are powerful pedagogical works aimed at denouncing human errors and blindness in the face of technology. They are a call to vigilance and action. It is no longer possible to say that we did not know. It is also a first step towards a change in behaviour, synonymous with environmental education.

\section{Environmental education, an inspiration from the 1970s}

Even if environmental education was influenced by the opposition between Muir's preservationist thinking (biocentric and based on the representation of a wild and unspoilt nature) and Pinchot's conservationist thinking (more eco-centred and based on a rational use of its resources), it only obtained its true nobility in the early 1970s. Of Anglo-Saxon inspiration, it has led to the emergence of different currents of thought that are grouped under the banners of positivism (the field of quantitative research that excludes any subjective analysis, that relies on observed phenomena, that rejects any form of doubt or ambiguity); constructivism (this places the individual and his representations at the centre of the construction of reality); and critical theory (L. Sauvé1997, p. 170), which highlights the very close link between theory and action, reveals the predominant influence of the individual's social and historical context, insists on the need to clarify theories, and proposes a critical approach to social realities). UNESCO defined environmental education in 1972 (Giordan, Souchon, 1991), in France, it was a circular of 1977 (August, 29 ${ }^{\text {th }}$ ) that specified the contents and methods of environmental education. The definition of the environment is quite broad, referring to "all, at a given time, to the physical, chemical, biological and social and economic aspects likely to have a direct or indirect, immediate or long-term effect on living beings and human activities". Philippe Mérieu (2001, p. 3-4) evokes four types of reasoning to justify the need to educate people about the environment: "It is a contemporary concern", "behaviourist logic: children must be allowed to acquire reflexes, to adopt behaviours that have become necessary for the very survival of the planet", "Environmental education makes it possible to introduce a new approach, an original way of thinking about the world as a complex system constituted by a multitude of interacting elements", "its function of social criticism". Environmental Education (EE) emerged in the same year at the Stockholm UNCSD. It is conceived as a process in which individuals and the community are made aware of their environment and acquire the knowledge, values, skills, experience and also the willingness to act, individually and collectively, to solve current and future environmental problems. Lucie Sauvé (1998, p. 15) points out that "EE is considered as this dimension of contemporary education that is concerned with rebuilding the network of relationships between people - social group - environment". The environment is thus an eco-socio-system, characterized by the interaction of its biophysical and social components.

The originality of EE lies mainly in the conflict inherent between the two interpretation of environmental education. The first one focuses on people, the second on the environment. The challenge is to work at the heart of this conflict to create new social dynamics that are located in time and space. EE analyses a contextualized reality and is defined by goals and values (Sauvé, 1991). The environment, being a social object, unlike nature, exists only through the way we look at it. The study of the environment is therefore fundamentally anthropocentric because it explores man's cultural and contextual relationship with the environment. "The individual is part of the system he perceives and the strategies he adopts become an integral part of the environment, which he in turn sees as external to himself. Ways of looking at the environment are therefore, in a very broad sense, a function of what is done there, including the strategies deployed to explore and understand it. And what is done in the environment is in turn one of many possibilities" (Ittelson, 1991). The environment only exists when man is present and concerned, so it is anchored in our cultures and social systems (Theys, 1993). 
The environment can be summarized as the space in which we live, in which we evolve, which provides us with our resources, our well-being and for which we are responsible; it can be open to the notion of community, when it is associated with a particular territory, a particular local or more distant identity. Manbecomes an active subject and shares values with his community neighbours (Giolettito, Clary, 1995). The environment then takes on a solidarity dimension, generating social cohesion, carrying a present and future life project. Environmental Education has this ambition because it embraces the dimensions of identity (autonomous self and individual responsibility), social (social self and responsibility to others), and earth (being alive and responsibility towards other living beings), and of Man as interrelated spheres contributing to his personal and social development (Desautels, 1998; Sauvé, 2012). Popular education networks such as CPIEs are part of this educational movement. They reflect the emergence of new pedagogies, such as project pedagogy, which has the aim of developing responsible skills based on strategies of citizen engagement.

\section{Education for sustainable development, more transversal}

It is difficult to imagine a universal model of education for sustainable development, as each country must define its objectives, priorities, programme of action, and how they are to be assessed. Economic, environmental, social, religious, and cultural conditions are such that ESD can take different forms. Nevertheless, it is possible to specify the essential characteristics of education for sustainable development and to define the contours of its theoretical framework.

In a decade, Education for Sustainable Development succeeded in establishing itself in the educational landscape at national and international levels. In December 2002, the United Nations General Assembly adopted resolution 57/254 proclaiming the United Nations Decade of Education for Sustainable Development (2005 - 2014). This initiative completed a series of texts (Chapter 36 of Agenda 21, provision 124) adopted at the United Nations Conference on Environment and Development (Rio de Janeiro, June 1992) and the World Summit on Sustainable Development (Johannesburg, September, 2002). UNESCO was designated as the lead agency for the promotion of this Decade. As early as 2005, UNESCO's expectations were clearly defined: "Throughout the Decade, education for sustainable development will contribute to enabling citizens to face the challenges of the present and future and leaders to make relevant decisions for a viable world. These actors will have acquired various skills (critical and creative thinking, communication, conflict management and problem solving strategies, project assessment) to take an active part in and contribute to the life of society; be respectful of the Earth and life in all its diversity; and be committed to promoting democracy in a society without exclusion and where peace prevails" (2005b, p. 4). To implement the objectives mentioned above, the Decade proposed to focus on four targets.

\section{Figure 2: Implementation of the Decade}

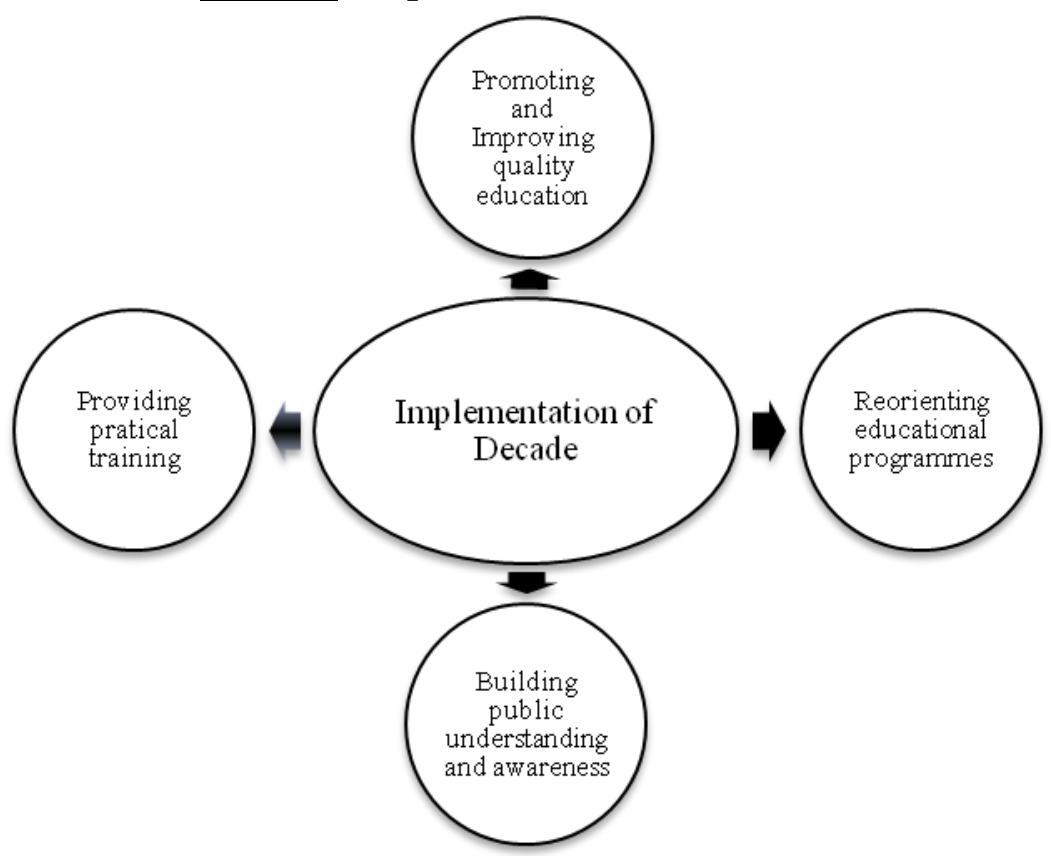


Promoting and improving quality education reminds us that basic education needs to focus on shared knowledge, skills, values, and perspectives through a lifetime of learning. Reorienting educational programmes means rethinking and revising education programs from nursery school to university to improve sustainability. Building public understanding and awarenessis a means of achieving the goals of sustainable development and encourage active citizenry. Providing practical training engages all the sectors develop the knowledge and the skills necessary for sustainability. The challenges were to go beyond environmental education, to draw up an inventory of what exists in the world, to mobilize all the actors and especially the media, to establish partnerships and create synergies between the initiatives and programmes.

\subsection{The three challenges of ESD}

An international implementation scheme was designed. Three challenges were given particular attention: sustainability issues, the role of values, and the links between different United Nations initiatives.

- Sustainability issues: Education for sustainable development must prepare "people of all walks of life to plan for, cope with, and find solutions for issues that threaten the sustainability of our planet" (UNESCO, 2005a, p. 7). Most of these issues were addressed at the Earth Summit (Rio de Janeiro, 1992) and then redefined at the World Summit on Sustainable Development (Johannesburg, 2002). These include the problem of access to water (source of conflict), the energy issue (more specifically the slow implementation of renewable energies), biodiversity (definition of property rights in the face of bio-piracy activities by major pharmaceutical groups in the South(Vogel and al, 2000), and health (many populations are exposed to malaria and AIDS). In its point 5, the Johannesburg Declaration recalls that all these issues are the responsibility of states, are part of a spatial and temporal scale, and refer to the three pillars of sustainable development - environment, society, and the economy: "As such, we assume our collective responsibility to advance at the local, national, regional and global levels economic development, social development and environmental protection as independent and complementary pillars of sustainable development". The action plan, specified in point 11 of the same declaration, specifies that "the eradication of poverty, the adaptation of consumption and production patterns, as well as the management of the stock of natural resources necessary for economic and social development are key objectives of sustainable development, and are also its preconditions". The concept of sustainability is both complex and multifaceted (waste management is mixed with the defence of human rights, poverty reduction, population migration, climate change, etc.). To address all these issues, it was necessary to implement innovative educational strategies (to put it bluntly, the aim is educational reform), which could bring about profound changes in citizens' behaviour.

- Values: To bring about this change in mentalities and to move into the 21st century, states have to rely on the values that have forged their identity. The challenge of Education for Sustainable Development does not mean making a "clean slate" of history and culture and opposing traditional society to techno-society, but understanding its own values, those of the society in which we live, and those of other societies. This is an essential aspect of education for sustainable development, "each nation, cultural group and individual must learn the skills of recognizing their own values and assessing these values in the context of sustainability" (UNESCO, 2005, p. 7). It is difficult to draw up an exhaustive list of values, some of them refer to ideas of justice (human rights, equity, equality), respect (for others, for nature), emotions (sympathy, empathy, apathy), principles (participation, solidarity, precaution, responsibility). In addition, there could be a lengthy discussion on the values that should be introduced into educational programmes. Education for sustainable development emphasizes, above all, the question of the transmission of values, the inter-generational heritage must enable us to identify locally relevant and culturally appropriate values, and is the fourth pillar of sustainable development, culture.

- Linking the Decade to other international educational priorities: ESD must be placed among UNESCO's other initiatives. These include the Millennium Development Goals (MDGs), Education for All (EFA) and the United Nations Literacy Decade (UNLD). All these initiatives treat basic education as important, wishing both to extend it to all continents (especially Africa) and to improve its quality. 
Table 2: ESD and other international Priorities

\begin{tabular}{|c|c|c|c|c|}
\hline Programmes & MDG & EFA & UNLD & ESD \\
\hline Objectives & $\begin{array}{l}8 \text { objectives } \\
\text { 1. Eradicate extreme } \\
\text { poverty and hunger } \\
\text { 2. Achieve universal } \\
\text { primary education } \\
\text { 3. Promote gender } \\
\text { equality and empower } \\
\text { women } \\
\text { 4. Reduce child } \\
\text { mortality } \\
\text { 5. Improve maternal } \\
\text { health } \\
\text { 6. Combat HIV/AIDS, } \\
\text { malaria and other } \\
\text { diseases } \\
\text { 7. Ensure environmental } \\
\text { sustainability } \\
\text { 8. Establish a } \\
\text { sustainable partnership } \\
\text { for development }\end{array}$ & $\begin{array}{l}\text { 6 objectives } \\
\text { 1. Expand and improve all aspects of early } \\
\text { childhood care and education. } \\
\text { 2. Ensure that by } 2015 \text { all children, } \\
\text { particularly girls, children in difficult } \\
\text { circumstances and those belonging to ethnic } \\
\text { minorities, have access to and complete free } \\
\text { and compulsory primary education of good } \\
\text { quality. } \\
\text { 3. Ensure that the learning needs of all young } \\
\text { people and adults are met through equitable } \\
\text { access to appropriate learning and life-skills } \\
\text { programmes. } \\
4 \text {. Achieve a } 50 \% \text { improvement in levels of } \\
\text { adult literacy by } 2015 \text {, especially for women, } \\
\text { and equitable access to basic and continuing } \\
\text { education for all adults. } \\
\text { 5. Eliminate gender disparities in primary and } \\
\text { secondary education by } 2005 \text { and achieve } \\
\text { gender equality in education by } 2015 \text {, with a } \\
\text { focus on ensuring girls' full and equal access to } \\
\text { and achievement in basic education of good } \\
\text { quality. } \\
6 \text {. Improve all aspects of the quality of } \\
\text { education and ensure excellence of all, so that } \\
\text { recognized and measurable learning outcomes } \\
\text { are achieved by all, especially in literacy, } \\
\text { numeracy and essential life skills. }\end{array}$ & $\begin{array}{l}3 \text { objectives } \\
\text { 1. Mobilize a stronger } \\
\text { commitment to literacy; } \\
2 \text {. Strengthen the } \\
\text { effectiveness of the } \\
\text { implementation of } \\
\text { literacy programmes; } \\
\text { 3. Mobilize new } \\
\text { resources for literacy. }\end{array}$ & $\begin{array}{l}4 \text { objectives } \\
\text { 1. Facilitate } \\
\text { networking, linkages, } \\
\text { exchanges and } \\
\text { interactions among } \\
\text { stakeholders in ESD; } \\
\text { 2. Contribute to } \\
\text { improving the quality } \\
\text { of teaching and } \\
\text { learning in education } \\
\text { for sustainable } \\
\text { development; } \\
\text { 3. Assist countries to } \\
\text { make progress towards } \\
\text { the achievement of the } \\
\text { Millennium } \\
\text { Development Goals } \\
\text { through efforts on } \\
\text { education for } \\
\text { sustainable } \\
\text { development; } \\
\text { 4. Provide countries } \\
\text { with new opportunities } \\
\text { to integrate education } \\
\text { for sustainable } \\
\text { development into their } \\
\text { educational reform } \\
\text { efforts. }\end{array}$ \\
\hline
\end{tabular}

In its 2014 report, UNESCO stated that ESD "aims at encouraging the transformation of education so that it is able to contribute effectively to the reorientation of societies towards sustainable development... requires participatory teaching and learning methods like critical thinking, imagining future scenarios and making decisions in a collaborative way in order to empower learners to take action for sustainable development" (2014, p. 20). The report also pointed out that initiatives from south countries had revealed some key points (Khushik, Diemer, 2018) -(i) Education for Sustainable Development has stimulated pedagogical innovation. Education policies (including curriculum reform) have encouraged learning for sustainable development in many countries, from early childhood education to training in the private sector. (ii) Education for Sustainable Development has succeeded in bringing together all levels and fields of education - formal, non-formal, and informal. (iii) Education for Sustainable Development has highlighted the role of stakeholders and partnerships in the implementation of educational programmes.

\subsection{Issues for ESD}

However, these achievements do not exhaust the subject and the challenges to be faced are still numerous:

Education for Sustainable Development is not completely integrated into sectoral policies; the place of ESD in early childhood is very heterogeneous across countries (significant gaps in programme accessibility and quality); ECCE (Early Childhood Care and Education) educators do not always have the skills to incorporate ESD into their teaching; much remains to be done to integrate ESD into technical and vocational education and training in both formal and informal contexts; the compartmentalization of disciplines continues to hinder the analysis of complex problems and prevents learners from acquiring the capacity to address complexity; accessibility to ESD in adult learning and education remains difficult, which hinders the dissemination of concepts and practices of sustainable development among adult learners; it is essential to reorient private sector education and training so that education defines the skills needed for critical analysis of the whole system, collaborative problem solving and decision-making. Finally, there is a need to build the capacity of all stakeholders to work in partnership and, in particular, to better understand the social learning process and measures for evaluating and improving outcomes.In 2015, the lessons of the Decade and the challenges ahead guided the Global Action Programme for ESD (resolution 37C/12). Five priority areas for action were identified: (i) policies to support ESD; (ii) a transformation of learning and training environments; (iii) capacity building for educators and trainers; (iv) youth empowerment and mobilization; (v) accelerating the search for sustainable solutions at the local level. 


\section{Figure 3: Priority Action Areas}

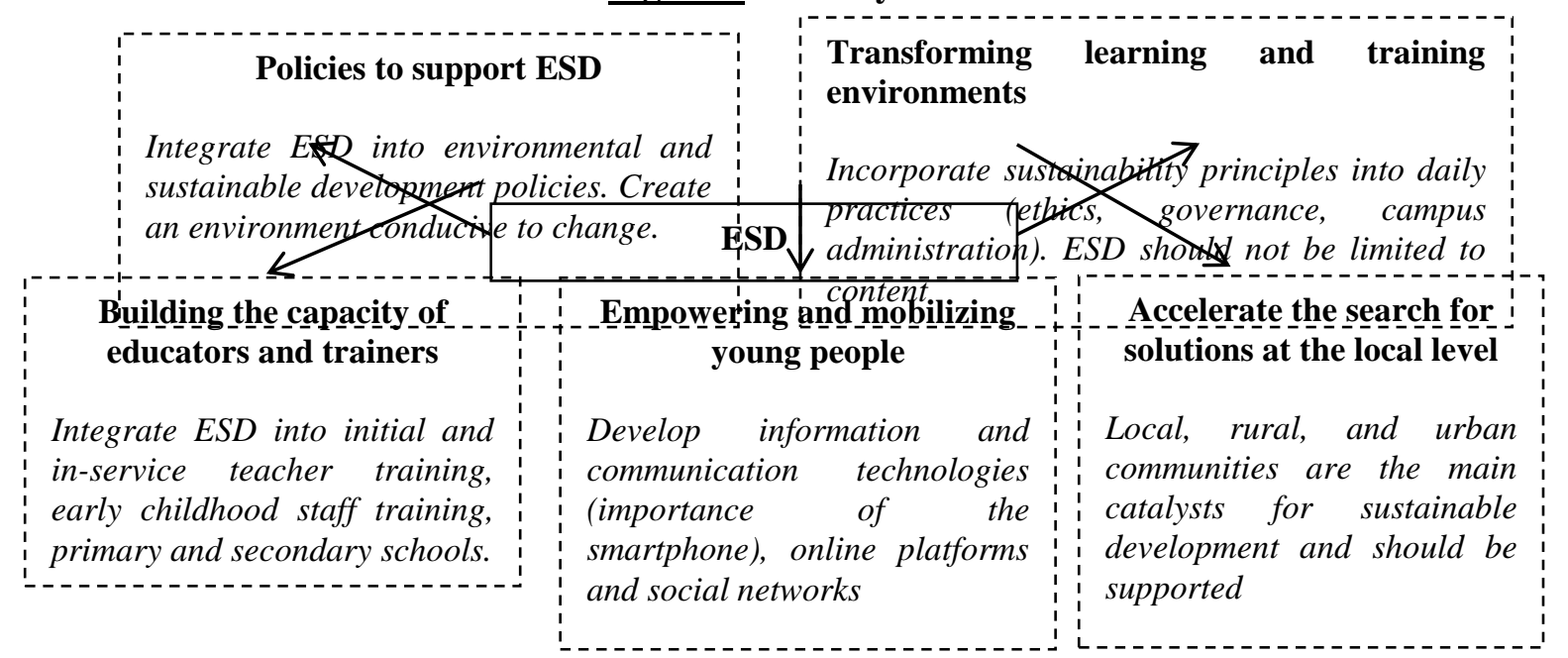

If these 5 priority areas of action are a call for commitments (over 5 years) from all stakeholders to support the implementation of ESD worldwide, they once again place ESD within a framework of good practice and action in the educational field (UNESCO, 2012). ESD projects focus on a number of criteria such as the needs of populations; the consideration of shared values (cultural and universal); the presence of partnerships from the social and local fabric; the development and dissemination of information and communication through networks, etc. They emphasize a fundamental point of education for sustainable development: the reflective approach. It is an essential component to develop the skills leading to autonomy and responsibility. The reflective approach makes it possible to move forward by regularly looking back, by asking questions such as: does the methodology meet the objectives set? Is it effective? Does it allow the community of actors to be involved? What are the identifiable consequences?

It should be noted that in 2012, UNESCO published a report on good practice in biodiversity education. This underlined an important fact: the educational community increasingly recognized biodiversity education as an essential component of ESD and lifelong learning (2010 was the International Year of Biodiversity in Schools). These good practices in Namibia (Namibia Desert Environmental Education Fund), China (Shangri-la Sustainable Communities Institute), Japan (Regional Centre of Expertise for ESD in the Sendai Metropolitan Area) and Jordan (Royal Society for Nature Conservation) have enabled the involvement of various stakeholders, the creation through networks of a community of learners, the adoption of new norms and behaviours by learners, the transformation of these norms and behaviours into models in the community.

In 2018, UNESCO placed ESD at the heart of the 2030 Agenda for Sustainable Development and its 17 Sustainable Development Goals (United Nations, 2015). The SDGs recognize that all countries should stimulate action in the following key areas - People, Planet, Prosperity, Peace, and Partnership (the Five Ps) - in order to tackle the global challenges that are crucial for the survival of humanity.

ESD is explicitly mentioned in target 4.7: "By 2030, ensure that all learners acquire the knowledge and skills needed to promote sustainable development, including, among others, through education for sustainable development and sustainable lifestyles, human rights, gender equality, promotion of a culture of peace and nonviolence, global citizenship and appreciation of cultural diversity and of culture's contribution to sustainable development" (UN, 2015, p. 19). For UNESCO, the five priority action areas are intended to increase the number of countries that have integrated ESD into education and sustainable development policies, and so to catalyse ESD's capacity to help achieve global commitments (as part of the Paris Agreement on Climate change ESD introduced the Education for Climate Change (ECC)). ESD requires changes in education systems, including strengthening curricula, innovative pedagogies and teacher training, but above all a conceptual and methodological model for transforming education systems.

\section{Conclusion}

In an article published in 2013, Patrick Matagne questioned a double rupture (societal and epistemological) between Environmental Education and Education for Sustainable Development. He said that the concept of the environment, initially a disciplinary one, had become "nomadic", enriched by multidisciplinary knowledge, 
affecting geography and ecology, art and history -Environmental Education had also become polysemous, based on an amalgam of knowledge, practices and values - making it more complex. Education for Sustainable Development is also an education for complexity, but unlike environmental education, it has never been a disciplinary concept. Sustainable development has developed in a context of crisis, around major fields of activity - economic, social, political, cultural and scientific - which has increased its complexity. The ESD curriculum often uses both scientific concepts, and many non-scientific references (social consensus, "good practices"), and refers in a recurrent way to the question of values to be transmitted and shared or to the different postures induced by the concepts and representations of the different actors of an educational project oriented towards ESD.

Beyond the good practice and guidelines, ESD has to be implemented in education on strong conceptual and methodological foundations. From the conceptual point of view, ESD involves controversial issues, complexity, transdisciplinarity, systemic approach, principles, and values. From the methodological point of view, ESD introduces a new framework. The REDOC is an educational model which analyses people's representations, uses pedagogical methodology, proposes didactic tools and suggests new skills. As education seems to be the new vehicle for better sustainability, it is necessary to engage world's citizens in order to change their behaviour and accept more responsibility.

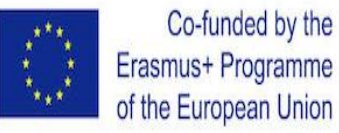

Funding:Research article has receivedfundingfrom the Eurasmus Programme of the European Union

CompetingInterests:The authorsdeclarethatthey have no competinginterests.

Contributors/Acknowledgement:All authorscontributedequally to the conception and design of the study.

\section{Bibliography}

Ackbarally, N. (2013). Climate Change Teaches Some Lessons. Interpress Service News Agency. http://www.ipsnews.net/2013/07/climate-change-teaches-some-lessons.

Akkari, A., Payet, J.P. (2010). Transformations des systèmes éducatifs dans les pays du Sud. Entre globalisation et diversification.Raisons éducatives. $336 \mathrm{p}$.

Alaya, A. (2010).L'Education à l'Environnement en Tunisie. Analyse des valeurs relatives à la nature et à l'environnement dans les conceptions d'enseignants et d'élèves et dans les manuels scolaires. Thèse UniversitésLyon 1 et Tunis 1 (ISEFC).

Astofi, J.P., Darot, E., Ginsburger-Vogel, Y., Toussaint, J. (1997).Mots-clés de la didactique des sciences. Paris Bruxelles : De Boeck Université.

Bader, B., Sauve L. (2011). Education, Environnement et développement durable: vers une écocitoyenneté critique. Presses de l'Université de Laval. Canada.

Bigohe J.B., Kiaya, N., Mimboro, D., Binzangi, K. (2014). L'enseignement de l'éducation au développement durable à l'école primaire en RDC: état des lieux et perspectives. InA. Diemer\& C. Marquat (Eds), Eduquer au développement durable (pp. 451 - 468).De Boeck.

Figuière, C., Bodin, B., Diemer, A. (2014). Economie politique du développement durable. De Boeck.

BougrainDubourg, A., Dulin, A. (2013).L'éducation à l'environnement et au développement durable tout au long de la vie, la transition écologique. Les avis du Conseil Economique Social et Environnemental. Décembre. $120 \mathrm{p}$.

Bregeon, J. (2008). Rapport du groupe de travail interministériel sur l'éducation au développement durable.

Brousseau, G. (1998). Théorie des situations didactiques. Grenoble. La Pensée Sauvage.

Carson, R. (1962). SilentSpring. Houghton MifflinCompany Boston.

Clément, P., Caravita S. (2011).Education pour le développement durable, et compétences des élèves dans l'enseignement secondaire. Unesco, $95 \mathrm{p}$.

Cole, M. (1991). On socially shared cognition. In L.B. Resnick, J. Levine, S.D. Behrend (Eds.), Perspectives on socially shared cognition. Washington, DC: American Psychological Association.

Commoner, B. (1971).The Closing Circle, Alfred A. Knopf Editions. New York.

Danic, I. (2006). La notion de représentation pour les sociologues : Premier aperçu.ESO,25, 29 - 32.

Diemer, A. (2016).Le développement durable et les économistes. Editions Oeconomia. 
Diemer, A., Marquat C. (2015a). L'éducation au développement durable, quels enjeux pour les ESPE ? Le printemps de la recherche, réseau ESPE, 23 mars, Paris, 10 p.

Diemer, A., Marquat, C. (2015b).Regards Croisés Nord Sud sur le développement durable.De Boeck.

Diemer, A., Marquat, C. (2014).L'éducation au développement durable. Editions De Boeck.

Diemer, A. (2013a). L'éducation au développement durable, une affaire de représentation. Revue Francophone du développement durable, 1, mars, $30-59$.

Diemer, A. (2013b). L'éducation systémique, une réponse aux défis posés par le développement durable.Education relative à l'environnement, 11, $27-42$.

Diemer, A. (2011). De la représentation du développement durable à la construction de savoirs transversaux, Les cahiers du CERIUM, Montréal, septembre-octobre, 1- 28.

Doise, W., Mugny, G. (1981). Le développement social de l'intelligence. Paris: InterEditions.

Fabre, M. (2014). Les éducations à: problématisation et prudence.Les cahiers du CERFE,Education et socialisation, 36 .

Freire, P. (1974).La pédagogie des opprimés,Maspéro.

Fisher, G.N. (1987), Les concepts fondamentaux de la psychologie sociale. Paris, Dunod.

Girault, Y., Lange, J.M, Fortin-Debart, C., Simonneaux, L., Lebeaume, J. (2007). La formation des enseignants dans le cadre de l'éducation au développement durable : problèmes didactiques.Éducation relative à l'environnement, 6, 119-136.

Goffin, L. (1997).L'éducation relative à l'environnement, un défi pour le XXIème siècle. Conférence forum international Planèt' ErE, Montréal.

Goffin, L. (1992).Problématique de l'environnement.Fondationuniversitaireluxembourgeoise - Arlon.

Hanh ThichNhat (2011).Planting seeds, Practicing Mindfulness with children. Parallax press.

Hubert, M. (1999). Apprendre en projets. Lyon: Chroniquesociale.

Hor, K. (2014).An Advocacy Journey towards Education for Sustainable Development in Singapore. http://www.theodyssey.sg/resources/advocacy-journey-towards-education-sustainable -developmentsingapore.

Lange, J.M. (2014). Education au développement durable: intérêts et limites d'un usage scolaire des investigations multi-référentielles d'enjeux, Cahiers du CERFEE, Education et socialisation, 36.

Lange, J.M., Martinand, J.L. (2010). Éducation au développement durable et éducation scientifique : balises pour un curriculum. In A. HASNI \& J. LEBEAUME (Eds), Nouveaux enjeux de l'éducation scientifique et technologique : visées, contenus, compétences, pratiques (pp. 125 -154). Presses de l'université d'Ottawa.

Lange, M.F. (2001). Dynamiques scolaires contemporaines au Sud. In M.F. Lange (Ed.), Des écoles pour le Sud. Stratégies sociales, politiques étatiques et interventions du Nord. Autrepart, 17, pp. 5-12.

Legardez, A., Alpe, Y. (2013). Le curriculum sournois de l'éducation au développement durable : l'exemple de l'usage de certains concepts, Revue Francophone du développement durable,1, mars, pp. 91 - 108.

Legardez, A., Simonneaux, L. (2011).Développement durable et autres questions d'actualité. Questions socialement vives dans l'enseignement et la formation,Educagri.

Legardez, A. (2004). Transposition didactique et rapports aux savoirs : l'exemple des enseignements de questions économiques et sociales, socialement vives. Revue française de pédagogie, 149, 19 - 27.

Matagne, P. (2013). Education à l'environnement, éducation au développement durable, la double rupture.Education et socialisation, 33, $9 \mathrm{p}$.

Meirieu, P. (2001).Eduquer à l'environnement : pourquoi ? Comment ? Conférence, 17p.

Meirieu P. (1987). Apprendre ... oui, mais comment. Paris. ESF (1999), $17^{\mathfrak{e}}$ édition.

Nicolescu, B. (1996), La transdisciplinarité. CIRET.

Or2d (2014). Quelles compétences pour favoriser le passage de l'éducation à l'environnement à l'éducation au développement durable.Rapport intermédiaire, IFADEM, décembre, 51 p. http://www.or2d.org

Pavlova, M. (2007). Two pathways, one destination: TVET for a sustainable future. Background paper for the virtual Conference. UNESCO-UNEVOC, 22 octobre - 10 novembre.

Pellaud, F. (2011). Pour une éducation au développement durable.Quae Editions.

Piaget, J. (1937).La construction du réel chez l'enfant. Paris Delachaux et Niestlé.

Rosnay, de J. (1977).Le macroscope.Editions du Seuil.

Rosnay, de J. (1991).L'écologie et la vulgarisation scientifique.Musée de la Civilisation. 
Sarabhai, K. V., Subramaniam, S.M. (2014).ESD and Biodiversity Education. Background paper for the DESD Global. Monitoring and Evaluation Report.

Sauve, L. (1997). Pour une éducation relative à l'environnement.Montréal: GuérinÉditeur.

Siraj-Blatchford,J. (2014). Matarajio' project: Gender equality in Kenya. http://327sustainability.wordpress.com/2014/06/03/matarajio-project-gender-equality-in-kenya.

Sauve, L. (1994).Pour une éducation relative à l'environnement. ESKA, Paris.

Simonneaux, J. (2013). Quelques postures épistémologiques pour une éducation au développement durable ?,Revue Francophone du développement durable, 1, mars, pp. 75 - 90.

Tostan (2013). Seven Female Solar Engineers Share Knowledge at Tostan Solar Power Workshop.Dakar.

Unesco (2018). Issues and trends in Education for Sustainable Development, Education on the move, Education 2030,Leicht A., Heiss J. and Byun W.J (Eds.), Unesco France, 271 p.

Unesco (2014). Shaping the Future we want, UN Decade of Educationfor Sustainable Development (2005 2014).Final Report, Unesco France. Paris, ISBN 978-92-3-100053-9, 198 p.

Unesco (2012).Education pour le développement - Bonnes pratiques en matière de biodiversité,6, UNESCO secteur de l'éducation. Paris. France, 112 p.

Unesco (2009).Review of Contexts and Structures for Education for Sustainable Development, 84 p.

Unesco (2006).L'éducation non formelle. Bureau de l'information au public, 2 p.

Unesco (2005a).United Nations Decade of Education for Sustainable Development (2005 - 2014). International Implementation Scheme, Unesco Education Sector, ED/DESD/2005/PI/01, 31 p.

Unesco (2005b).UN Decade of Education for Sustainable Development, 2005 - 2014. ED/2005/PEQ/ESD/3, Division for the promotion of Quality Education., $10 \mathrm{p}$.

Unesco (2005c).Unesco and Sustainable Development, 44 p.

Unesco (1996).Learning, a treasure within. Paris, 51 p.

United Nations (2015). Transforming our world: The 2030 Agenda for Sustainable Development, A/RES/70/1,41 p.

Vogel, J.H., Alarcon, R., Saenz Garcia M., Morales, M., Lindstrom, R. (2000).El Cartel de la biodiversidad. CARE, Proyecto SUBIR.

Vygostky, L.S. (1934).Pensée et langage. Paris. Editionssociales (1985).

Wals A. E. J. (2014).Social Learning-oriented ESD: meanings, challenges, practices and prospects for the postDESD era. Background paper for the DESD Global Monitoring and Evaluation Report. 